\title{
Detection of Hepatitis E Virus Antibodies in Domestic and Wild Animal Species in Central Italy
}

\author{
Maurizio Mazzei ${ }^{1}$, Mario Forzan ${ }^{1}$, Federica Pizzurro ${ }^{1}$, Federico Picciolli ${ }^{2}$, Patrizia Bandecchi ${ }^{1}$ and Alessandro Poli ${ }^{{ }^{*}}$ \\ ${ }^{1}$ Department of Veterinary Sciences, University of Pisa, Pisa, Italy \\ ${ }^{2}$ D.R.E.Am. Italia, Section wildlife management, Via E. Bindi, 14-51100 Pistoia, Italy
}

"Corresponding author: Alessandro Poli, Department of Veterinary Sciences, Viale delle Piagge, 2, I-56124 Pisa, Italy, Tel: +39-050-2216982; Fax +39-050-2216941; E-mail: alessandro.poli@unipi.it

Received date: November 24, 2015; Accepted date: December 23, 2015; Published date: December 30, 2015

Copyright: $\odot 2015$ Mazzei M, et al. This is an open-access article distributed under the terms of the Creative Commons Attribution License, which permits unrestricted use, distribution, and reproduction in any medium, provided the original author and source are credited.

\begin{abstract}
Hepatitis E virus (HEV) is known for its zoonotic potential. Although several mammalian species have been indicated as possible viral reservoir, the host range of the infection is partially defined. In this work serum samples collected from wild brown hares, red deer, wild rabbits, cattle living in semi-wild state and wild boar-hunting dogs were tested by a multi-species ELISA assay. Only sera from red deer $(5.6 \%)$, wild rabbit $(38.5 \%)$ and wild-boar hunting dogs $(14.3 \%)$ scored positive. The investigation indicated the circulation and the high endemicity of HEV in various animal species in Central Italy, and the importance that these species can play in the epidemiology of infection.
\end{abstract}

Keywords: ELISA; Hepatitis E virus, Italy; Serology; Zoonosis

\section{Introduction}

Hepatitis E virus (HEV) is a well-recognised emerging pathogen distributed worldwide [1]. HEV is a small icosahedral non-enveloped and single-stranded positive-sense RNA virus. It has been designated as the sole member of the genus Hepevirus in the family Hepeviridae on account of its unique genomic organization [2].

The HEV genome is about $7.2 \mathrm{~kb}$ long and it contains 3 open reading frames (ORFs) as well as $5^{\prime}$ and $3^{\prime}$ untranslated regions. According to genomic differences $\mathrm{HEV}$ has been organized in 4 different genotypes and 1 serotype. Genotype 1 and 2 are isolated in humans while genotype 3 and 4 are zoonotic agents associated with sporadic outbreaks of HEV worldwide [3,4].

Several aspects regarding HEV biology have led to the hypothesis that more than an animal reservoir could be involved in the epidemiology of the virus. Interspecies transmission of HEV has been demonstrated by experimental infection and by genetic analysis of HEV positive samples of human and various animal hosts [5-7]. Although a high seroprevalence is found in pigs and wild-boar, other animal species such as rat, deer, dog, sheep, goat, rabbit, and cattle can also be considered as virus host species [8-11]. Due to the zoonotic potential of HEV it is essential to determine the full host range of the virus and the seroprevalence rate among wildlife animals, in order to control the spreading of the disease to domestic animals and exposed humans.

The purpose of our study was to investigate the presence of antiHEV antibodies in various wild and domestic animal species in Central Italy, an endemic area for wild-boar HEV infection [12-14].

\section{Materials and Methods}

In this study 214 sera belonging to wild brown hares (103), red deer (54), wild-boar hunting-dogs (35), wild rabbits (12) and cattle (10) were tested for the detection of HEV antibodies by multi-species ELISA kit (HEV Ab Version ULTRA, DIA.PRO Milano, Italy). The sera were collected from various sites and all belonging to a large geographical area located in Central Italy (Tuscany), populated by wild-boar with a high seroprevalence rate and with a clear evidence of viral circulation [12-14].

From March to September 2014, serum samples were collected from 54 red deer (40 females, 14 males), captured during the hunting season in the province of Pistoia, in north Tuscany, and from 12 wild rabbits (6 females and 6 males) shot in the province of Pisa in the west Tuscany, during the autumn of 2014.

Sera from 103 wild brown hares (50 females and 53 males) captured by nets from 2011 to 2015 in three different protected areas of the province of Pisa, were also investigated. The animals were stocked in wood cages and blood samples were collected through venipuncture of the saphenous vein prior to their reintroduction.

Blood samples were also collected from ten cattle during 2015 (1 male and 9 females) belonging to a farm where bovine are raised in semi-wild state with the possibility of contact or field sharing with other wild animals. Finally 35 sera from wild boar-hunting-dogs (17 females and 18 males) were collected during 2015 hunting season in the same areas submitted to investigation.

All the sera were classified and stored at $-20^{\circ} \mathrm{C}$ until tested by an ELISA assay following manufacturer's instruction.

The ELISA kit used is designed for the qualitative determination of total antibodies to HEV in serum and plasma samples. Derived by multi-species animals. The principle of the test is based on microplates coated with HEV-specific synthetic antigen. After the capture of anti$\mathrm{HEV}$ antibodies, if present in the sample tested, a second incubation is 
Page 2 of 4

performed by the addition of the same HEV highly specific antigen labeled with peroxidase. We considered positive only serum samples having an OD clearly above the assay cut-off value. The kit has a declared diagnostic sensitivity of $100 \%$ and an overall value for the diagnostic specificity of $>99.5 \%$.

\section{Results and Discussion}

A total of 214 sera were examined and seroprevalence from various species was calculated. None of the positive sera resulted equivocal.
The highest seroprevalence rate was detected in wild rabbit samples (38.5\%). This result is in agreement with published data recorded in other countries (Table 1) [15-25]. As previously demonstrated by Izopet et al. wild rabbits are one of the hosts for HEV suggesting their zoonotic potential [26]. Considering the high prolific rate of wild rabbits and therefore the high number of susceptible animals that could be constantly infected in a restricted area, their role for the epidemiology of HEV needs to be further investigated.

\begin{tabular}{|c|c|c|c|c|c|c|}
\hline \multirow[t]{2}{*}{ Animal Species } & \multicolumn{4}{|c|}{ Seroprevalence from literature ${ }^{*}$} & \multicolumn{2}{|c|}{ Seroprevalence in our study } \\
\hline & & & & & Percent & Positive/Total \\
\hline \multirow{3}{*}{ Red deer } & $1.10 \%$ & $1 / 84$ & $\mathrm{BE}$ & [15] & \multirow{3}{*}{$5.60 \%$} & \multirow{3}{*}{$3 / 54$} \\
\hline & $12.85 \%$ & $9 / 70$ & ES & {$[16]$} & & \\
\hline & $13.90 \%$ & $35 / 251$ & IT & {$[17]$} & & \\
\hline \multirow{3}{*}{ Rabbit } & $57.00 \%$ & $191 / 335$ & $\mathrm{CN}$ & [18] & \multirow{3}{*}{$38.50 \%$} & \multirow{3}{*}{$5 / 13$} \\
\hline & $36 \%$ & $31 / 85$ & US & [19] & & \\
\hline & $15.40 \%$ & $169 / 1094$ & $\mathrm{CN}$ & [20] & & \\
\hline Hare & & & & & $0.00 \%$ & 0/103 \\
\hline \multirow{4}{*}{ Cattle } & $6 \%$ & $6 / 100$ & $\mathrm{CN}$ & [22] & \multirow{4}{*}{$0.00 \%$} & \multirow{4}{*}{$0 / 10$} \\
\hline & $4.40 \%$ & $4 / 91$ & IN & [11] & & \\
\hline & $6.90 \%$ & $13 / 188$ & IN & [11] & & \\
\hline & $1.42 \%$ & $1 / 70$ & $\mathrm{BR}$ & [22] & & \\
\hline \multirow{6}{*}{ Dog } & $0.80 \%$ & $2 / 247$ & GB & [23] & \multirow{6}{*}{$14.30 \%$} & \multirow{6}{*}{$5 / 35$} \\
\hline & $17.80 \%$ & $18 / 101$ & $\mathrm{CN}$ & [21] & & \\
\hline & $21.12 \%$ & $139 / 658$ & $\mathrm{CN}$ & [24] & & \\
\hline & $13.50 \%$ & $26 / 192$ & $\mathrm{CN}$ & [25] & & \\
\hline & $22.70 \%$ & $10 / 44$ & IN & [11] & & \\
\hline & $6.97 \%$ & $3 / 43$ & $\mathrm{BR}$ & [22] & & \\
\hline
\end{tabular}

Table 1: Comparison of seroprevalence rates between data available in literature and the results of our study.

Our study showed a prevalence of $14.3 \%$ in wild-boar hunting-dogs which is also in accordance with similar studies (Table 1). Although the low number of sera examined in our survey does not allow a statistical analysis to determine significant risk of infection studies, the result is an important evidence of canine susceptibility to HEV infection. This aspect could be a veterinary public health problem considering that hunting dogs can easily be infected by direct contact with HEV infected wild boar or by consumption of contaminated material such as wild boar offals. However the zoonotic potential of $\mathrm{HEV}$ in dogs is still under discussion.

Finally, our survey shows a HEV seroprevalence of $5.6 \%$ in red deer, confirming previous results that indicate deer as one of the main reservoir of the virus in the wildlife [17].
All bovine and wild brown hare's samples resulted negative indicating that so far the virus seems not to circulate in these animals living in the examined area.

In the last decade, an increasing proportion of reported human HEV cases were demonstrated to be autochthonous [27], mainly linked to the ingestion of raw or undercooked meat or viscera of pigs, wild boar and deer [28-30]. Other studies focused the attention about the risk of infection encountered by humans with occupational exposure to pigs [31,32]. Moreover, the presence of seropositive wild animals in the study areas, could constitute a risk of HEV transmission through slaughtering by hunters as demonstrated by other studies $[13,33,34]$. Particularly intriguing is the high seroprevalence rate recorded in wild-board hunting-dogs, indicating the efficient 
transmission of the virus from wild animals to dogs. Although it is rather difficult to understand how exactly this transmission can be achieved, we should considered hunting dogs as a potential zoonotic host for HEV and therefore these animals should be further monitored in order to avoid possible transmission to humans; in particularly in owners and veterinarians.

In conclusion our data confirm that HEV infection has a wide distribution with different seroprevalence rates depending on the affected animal species and they reveal that HEV can easily circulate and spread in a Mediterranean ecosystem such as Central Italy.

\section{Aknowledgment}

Sera samples were taken for diagnostic purposes from hares captured in protected areas for further restocking of hunting areas and from legally hunted animals (red deer and wild rabbits), and from cattle raised in semi-wild state. Wild boar-hunting dog sera samples were further collected during veterinary cares in accordance with the ethical principles of animal experimentation as approved by the Ethical Committee "Unità etica e tutela animale della ricerca" Pisa University; prot $\mathrm{N}^{\circ}$ 23507. This work was funded by the Provincia of Pisa. We would thank all the hunters and the wildlife rangers of the sampled areas for their precious help in the field's activities and sampling.

\section{References}

1. Lee GY, Poovorawan K, Intharasongkroh D, Sa-Nguanmoo P, Vongpunsawad S, et al. (2015) Hepatitis E virus infection: Epidemiology and treatment implications. World J Virol 4: 343-355.

2. Emerson SU, Purcell RH (2003) Hepatitis E virus. Rev Med Virol 13: 145-154.

3. Okamoto H (2007) Genetic variability and evolution of hepatitis E virus. Virus Res 127: 216-228.

4. Purcell RH, Emerson SU (2008) Hepatitis E: an emerging awareness of an old disease. J Hepatol 48: 494-503.

5. Meng XJ, Halbur PG, Haynes JS, Tsareva TS, Bruna JD, et al. (1998) Experimental infection of pigs with the newly identified swine hepatitis $\mathrm{E}$ virus (swine HEV), but not with human strains of HEV. Arch Virol 143: 1405-1415.

6. Meng XJ, Halbur PG, Shapiro MS, Govindarajan S, Bruna JD, et al. (1998) Genetic and experimental evidence for cross-species infection by swine hepatitis E virus. J Virol 72: 9714-9721.

7. Halbur PG, Kasorndorkbua C, Gilbert C, Guenette D, Potters MB, et al. (2001) Comparative pathogenesis of infection of pigs with hepatitis E viruses recovered from a pig and a human. J Clin Microbiol 39: 918-923.

8. Tien NT, Clayson HT, Khiem HB, Sac PK, Corwin AL, et al. (1997) Detection of immunoglobulin $G$ to the hepatitis E virus among several animal species in Vietnam. American Journal of Tropical Medicine and Hygiene 57: 211.

9. Favorov MO, Nazarova O, Margolis HS (1998) Is hepatitis E an emerging zoonotic disease? American Journal of Tropical Medicine and Hygiene 59: 242.

10. Kabrane-Lazizi Y, Fine JB, Elm J, Glass GE, Higa H, et al. (1999) Evidence for widespread infection of wild rats with hepatitis $\mathrm{E}$ virus in the United States. Am J Trop Med Hyg 61: 331-335.

11. Arankalle VA, Joshi MV, Kulkarni AM, Gandhe SS, Chobe LP, et al. (2001) Prevalence of anti-hepatitis E virus antibodies in different Indian animal species. J Viral Hepat 8: 223-227.

12. Nardini R, Verin R, Mazzei M, Forzan M, Poli A (2014) Hepatitis E virusrelated liver alterations and viral antigen localization in European wild boar (Sus scrofa). European Journal of Wildlife Research. 60: 835-838.
13. Mazzei M, Nardini R, Verin R, Forzan M, Poli A, et al. (2015) Serologic and molecular survey for hepatitis E virus in wild boar (Sus scrofa) in Central Italy. New Microbes New Infect 7: 41-47.

14. Martinelli N, Pavoni E, Filogari D, Ferrari N, Chiari M, et al. (2015) Hepatitis $\mathrm{E}$ virus in wild boar in the central northern part of Italy. Transbound Emerg Dis 62: 217-222.

15. Thiry D, Mauroy A, Saegerman C, Licoppe A, Fett T, et al. (2015) Belgian Wildlife as Potential Zoonotic Reservoir of Hepatitis E Virus. Transbound Emerg Dis .

16. Kukielka D, Rodriguez-Prieto V, Vicente J, Sánchez-Vizcaíno JM (2015) Constant Hepatitis E Virus (HEV) Circulation in Wild Boar and Red Deer in Spain: An Increasing Concern Source of HEV Zoonotic Transmission. Transbound Emerg Dis.

17. Di Bartolo I, Ponterio E, Angeloni G, Morandi F, Ostanello F, et al. (2015) Presence of Hepatitis E Virus in a RED Deer (Cervus elaphus) Population in Central Italy. Transbound Emerg Dis .

18. Zhao C, Ma Z, Harrison TJ, Feng R, Zhang C, et al. (2009) A novel genotype of hepatitis $\mathrm{E}$ virus prevalent among farmed rabbits in China. J Med Virol 81: 1371-1379.

19. Cossaboom CM, Córdoba L, Dryman BA, Meng XJ (2011) Hepatitis E virus in rabbits, Virginia, USA. Emerg Infect Dis 17: 2047-2049.

20. Geng Y, Zhao C, Song A, Wang J, Zhang X, et al. (2011) The serological prevalence and genetic diversity of hepatitis $\mathrm{E}$ virus in farmed rabbits in China. Infect Genet Evol 11: 476-482.

21. Zhang W, Shen Q, Mou J, Gong G, Yang Z, et al. (2008) Hepatitis E virus infection among domestic animals in eastern China. Zoonoses Public Health 55: 291-298.

22. Vitral CL, Pinto MA, Lewis-Ximenez LL, Khudyakov YE, dos Santos DR, et al. (2005) Serological evidence of hepatitis E virus infection in different animal species from the Southeast of Brazil. Mem Inst Oswaldo Cruz 100: 117-122.

23. McElroy A, Hiraide R, Bexfield N, Jalal H, Brownlie J, et al. (2015) Detection of Hepatitis E Virus Antibodies in Dogs in the United Kingdom. PLoS One 10: e0128703.

24. Liang H, Chen J, Xie J, Sun L, Ji F, et al. (2014) Hepatitis E virus serosurvey among pet dogs and cats in several developed cities in China. PLoS One 9: e98068.

25. Liu J, Zhang W, Shen Q, Yang S, Huang F, et al. (2009) Prevalence of antibody to hepatitis E virus among pet dogs in the Jiang-Zhe area of China. Scand J Infect Dis 41: 291-295.

26. Izopet J, Dubois M, Bertagnoli S, Lhomme S, Marchandeau S, et al. (2012) Hepatitis E virus strains in rabbits and evidence of a closely related strain in humans, France. Emerg Infect Dis 18: 1274-1281.

27. Teshale EH, Hu DJ, Holmberg SD (2010) The two faces of hepatitis E virus. Clin Infect Dis 51: 328-334.

28. Matsuda H, Okada K, Takahashi K, Mishiro S (2003) Severe hepatitis E virus infection after ingestion of uncooked liver from a wild boar. J Infect Dis 188: 944.

29. Dalton HR, Bendall R, Ijaz S, Banks M (2008) Hepatitis E: an emerging infection in developed countries. Lancet Infect Dis 8: 698-709.

30. Romanò L, Paladini S, Tagliacarne C, Canuti M, Bianchi S, et al. (2011) Hepatitis E in Italy: a long-term prospective study. J Hepatol 54: 34-40.

31. Krumbholz A, Mohn U, Lange J, Motz M, Wenzel JJ, et al. (2012) Prevalence of hepatitis E virus-specific antibodies in humans with occupational exposure to pigs. Med Microbiol Immunol 201: 239-244.

32. Carpentier A, Chaussade H, Rigaud E, Rodriguez J, Berthault C, et al. (2012) High hepatitis E virus seroprevalence in forestry workers and in wild boars in France. J Clin Microbiol 50: 2888-2893.

33. Schielke A, Ibrahim V, Czogiel I, Faber M, Schrader C, et al. (2013) Hepatitis $\mathrm{E}$ virus antibody prevalence in hunters from a district in Central Germany, 2013: a cross-sectional study providing evidence for the benefit of protective gloves during disembowelling of wild boars. BMC Infect Dis 15: 440 . 
Citation: Mazzei M, Forzan M, Pizzurro F, Picciolli F, Bandecchi P, et al. (2015) Detection of Hepatitis E Virus Antibodies in Domestic and Wild Animal Species in Central Italy. Clin Microbiol 4: 227. doi:10.4172/2327-5073.1000227

Page 4 of 4

34. Ivanova A, Tefanova V, Reshetnjak I, Kuznetsova T, Geller J, et al. (2015)

Hepatitis E Virus in Domestic Pigs, Wild Boars, Pig Farm Workers, and

Hunters in Estonia. Food Environ Virol 7: 403-412. 